\title{
Jiné obory jako živý zdroj inspirace pedagogiky
}

\section{Hana Horká a Veronika Rodová}

\begin{abstract}
Milí čtenáři, přijměte pozvání do druhého čísla sedmdesátého prvního ročníku Pedagogiky. Texty, které se zde sešly, nám připomněly téma, které pedagogiku jako vědeckou disciplínu věrně provázejí. Stále hledáme přesná vymezení a formulujeme výstižná označení jevů, které se v praxi výchovy a vzdělávání odehrávají. Je to nutná podmínka stability vědecké disciplíny. Jan Průcha, přední český teoretik pedagogiky, který nás $\mathrm{k}$ naší velké lítosti opustil $\mathrm{v}$ polovině června letošního roku, v roce 1997 konstatoval, že terminologie pedagogiky není jednotná a význam řady termínu je nejasný. Obor trpí (často) nekritickým přejímáním termínů z angličtiny, zároveň česká terminologie mnohdy nestačí postihnout živou matérii praxe. To vytváŕí prostor pro terminologickou rozkolísanost a pojmové nepřesnosti. Domníváme se, že jeho slova mají platnost dodnes. Terminologie oboru se rozpíná a množí, někdy střídmě, jindy bez ohledu na pojmy již existující. Jde o jevy z oblasti sociální, tedy často těžko ohraničitelné a postižitelné. Nekrolog tohoto významného teoretika a pedagoga připravil Jiří Mareš.

Přejme oboru další badatele, kteří budou svým vědeckým snažením budovat shodu v chápání významu termínů a pěstovat srozumění v jejich užívání, a časopisu Pedagogika, jako místu, kde se terminologie a teorie oboru kultivuje, hodně zajímavých textů. Nyní se již věnujme krátkému přehledu obsahu tohoto čísla.

Autoři studie s názvem Gramotnosti ve vzděláváni - na cestě k vymezení jazykové gramotnosti, Martina Šmejkalová, Nad’a Vondrová, Irena Smetáčková a Martin Chvál, pracují s pojmem jazyková funkční gramotnost. V době, kdy jsme svědky postupně narůstajícího počtu gramotností (občas i za cenu relativizujících
\end{abstract}


a zpochybňujících interpretací), ji vnímají jako upozaděnou za gramotností čtenářskou. Vrátíme-li se k původnímu významu slova, jehož jádrem je řecké grámma (písmeno, psaní, nápis, mluvnice) a grápho (písii), je zřejmá souvislost s ukotvením gramotnosti v prostředí jazyka. Autoři chápou funkční jazykovou gramotnost jako „komplex znalostí, dovedností, schopností a postojů týkajících se užívání mateřského (prvního) jazyka v kontextu různorodých komunikačních událostí“. Vracejí se k původnímu významu gramotnosti jako trivia, tj. schopnosti číst, psát a počítat, a s tím korespondující gramotnosti čtenárské, jazykové a matematické. Poukazují na rozkolísání tradičního pojetí výuky českého jazyka a chtějí přispět $\mathrm{k}$ dialogu mezi školní praxí, školskopolitickými orgány a akademickou sférou. Dobrou znalost mateřského jazyka a schopnost jeho použivání ovlivňuje podle autorů úroveň všeobecné vzdělanosti společnosti a její systém hodnot. Zdůrazňují, že jazyk je hodnotou sám o sobě, protože představuje dědictví, které zrcadlí minulost, přítomnost a budoucnost, je obrazem myšlení i smýšlení společnosti. Je to nástroj, který máme všichni $\mathrm{k}$ dispozici. Chceme-li něco sdělit, bereme jej do ruky. Aby se neopotřeboval, je třeba o něj pečovat, zachovat a udržovat jeho živou barvitost a bohatství, pěstovat prostor našeho myšlení, který se stává prostorem našeho bytí.

Irena Smetáčková a Anna Vozková ve své studii Učitelské sdileni profesnich zkušenosti: aktuálni pohled z českých škol předkládají výsledky výzkumu zaměřeného na zjištění úrovně a způsobu výměny profesních zkušeností v učitelské komunitě. Předložený text nás vede $\mathrm{k}$ úvaze o proměnách jazyka a životnosti slov. Sdílení je dnes rozhodně frekventovanější termín než dřive. Jeho užití se rozšiřuje pod vlivem anglického jazyka (share, participate, spool, sympathize with) a otevírá konotace pro spolupráci, výměnu zkušeností a názorů $\mathrm{v}$ prostředí vzájemné důvěry. Autorky upozorňují na mělkou zakořeněnost konceptu profesního sdílení v české pedagogice, $\mathrm{v}$ jehož důsledku docházelo u respondentů výzkumu $\mathrm{k}$ odlišnostem $\mathrm{v}$ jeho chápání. Zaměřily se na aspekty sdílení zkušeností, pocitů a pochybností učitelů o svém pedagogickém působení. Nelze říci, že jde o zcela nový fenomén, protože i ve 20 . století měli učitelé možnost podělit se o informace a zkušenosti při vzájemných setkáních, hospitacích či vzdělávacích seminárích. Autorky zdůrazňují posun od tradiční představy učitelství jako individualizovaného až osamělého povolání - což může odkazovat k tradičnímu obrazu učitele jako obávané mocné (maskulinní) autority - $\mathrm{k}$ učiteli, který je otevřený vlastním úspěchům i neúspěchům a je schopen hledat cesty svého profesního rozvoje v součinnosti s kolegy. Prostor pro zveřejnění těchto, často i tacitních aspektů učitelova profesního působení může výrazně ovlivňovat vedení školy. Schopnost sdílet své zkušenosti, jak ukazují zahraniční prŕíklady, nespadne z nebe, ale je výsledkem dlouhodobého procesu vyžadujícího „kognitivní a emoční zapojení“ a také osobní zodpovědnost a schopnost otevřenosti a upřímnosti k sobě samému i vůči kolegům. Autorky věří, že kvalitu spolupráce v učitelských sborech ovlivňuje vedení školy a jeho způsob vytváření př́ležitostí pro profesní sdílení. 
Karel Rýdl přináší historiografickou studii věnovanou životě a díle Idy Jarníkové, významné reformní pedagožky předškolního vzdělávání, kterou bychom s nadsázkou mohli považovat za českou Marii Montessori. Když čtete životopis Jarníkové, nelze si nevšimnout, jak její profesní život nasměrovalo pochopení rodičů pro její „na tehdejší dobu silně nadprůměrný zájem o práci s malými dětmi“", což se u šestnáctileté Idy projevilo v péči o malé sourozence, zejména o benjamínka rodiny, Vojtěcha. Bedlivě pozorovala bratrův rozvoj, „analyzovala jeho potřeby a snažila se je maximálně naplňovat“. Rodiče brali dceřin zájem vážně a všemožně jej podporovali. Můžeme sledovat pestrou životní pout ženy, která svou neúnavnou odhodlaností a zájmem o rozvoj předškolních dětí zanechala hlubokou stopu $\mathrm{v}$ př́běhu předškolního vzdělávání a trvale ovlivnila pojetí této oblasti u nás.

Možná znáte situaci, kdy sedíte v divadle nebo v kině a všichni okolo se smějí, ale vy ne. Nebo naopak, vy se smějete, ale ostatní mlčí. Autoři článku Revize rozborů výzkumu efektu učitelova humorného pisobeni na výsledky učenížákì a studentü, Michaela Pejchalová a Miroslav Klusák, podrobují kritickému pohledu výzkumné studie různých autorů, kteří se tematice humoru věnují. Předložený přehled představuje zevrubné přemýšlení o zkoumaném tématu, kritická (a místy i kritizující) analýza upozorňuje na nesrovnalosti zkoumaných studií. Svým rozborem autoři chtěli „rozvinout a prohloubit“ pohled na roli humoru ve výuce. Jak humor ve výuce funguje? Co přináší ve vztahu $\mathrm{k}$ výukovým cílům? Jak ovlivňuje klima ve tř́idě? Autoři zkoumali sadu sedmnácti výzkumných studií, aby v nich hledali odpovědi na uvedené otázky. Jedná se o metaanalýzu textů, proto pojem humor autoři mnohokrát skloňují, ale neuvádějí jeho př́klady. Obsah slova humor tak získává neurčité obrysy a čtenář může přemýšlet, zda by si s autory rozuměl v tom, co je vtipné a co humor vlastně je. Co je humor? Muška jenom zlatá.

„Peníze se prostě vydělávají.“ „Mamka si je nosí z práce.“ „Někteří lidé ještě mohou peníze padělat nebo ukrást.“" „Máme je z banky, kde si ty peníze vyrábějí.“ „Hodně peněz si vydělávají třeba sportovci, třeba hokejisti...“, tak uvažují žáci ve věku 9-11 let ve výzkumném šetření, jehož data interpretuje a následně porovnává s výsledky zahraničních výzkumů z posledních třiceti let Michaela Dvořáková ve studii s názvem Odkud se berou: Dětská pojetí oběhu peněz. Poukazuje na složitost zkoumání dětských pojetí a na obtížnost jejich vyhodnocování z důvodu naivních představ a nepřesností, byt jde o fenomén peněz, se kterým jsou děti v každodenním kontaktu. Autorka se setkala $s$ řadou chybných či neúplných dětských pojetí, přesto se domnívá, že rozpoznaná pojetí oběhu peněz se mohou uplatnit v procesu konceptuální změny v konstruktivisticky pojaté výuce a obohatit tak oborovou didaktiku společenských věd. Do jaké míry se podařilo doplnit deficit výzkumu dětských pojetí pro oblast společenských věd a přispět k didaktickému uchopení témat finančního vzdělávání v primárním vzdělávání, se může stát předmětem diskuse s dalšími odborníky. 
Radmila Burkovičová se ve své studii Hodnocení pedagogické činnosti asistentky pedagoga v mateřské škole učitelkou zabývá vztahem učitelky a asistenta pedagoga v oblasti předškolního vzdělávání. Nastiňuje širší souvislosti pojmenování asistentské pozice u nás i v jiných evropských státech. Na základě analýzy legislativních dokumentů detekovala činnosti, které spadají do kompetence asistenta pedagoga. Jak skutečně vypadá činnost asistenta a vzájemná spolupráce ověřovala v rozhovorech s učitelkami MŠ. Šetření ukázalo, že spolupráce osoby v roli učitele a osoby v roli asistenta není samozřejmostí. Otevřelo téma důležitosti vzájemného respektu a profesionálního př́stupu založeného na profesních dovednostech i téma limitů profesionální podpory a odborného vedení ze strany učitelky. Způsobilost asistenta empaticky doplňovat práci učitele vede v ideálním př́ípadě ke vzájemné úctě, harmonii a spokojenosti, při nefungující spolupráci se objevuje nesnášenlivost, opovržení či známky rasistických postojů, což děti předškolního věku jistě intenzivně vnímají a možná i přejímají.

Analytická studie autorského týmu z Př́rodovědecké fakulty UK Petr Novotný, Vanda Janštová, Romana Schubertová, Karolína Kotvaltová Sezemská otevírá složité téma, dosud u nás nezpracovávané. Jak naznačuje název Národni odborné ćasopisy a analýza H-indexu členu jejich redakčnich rad, autoři přinášejí výsledky analýzy $\mathrm{H}$-indexu členů redakčních rad českých a slovenských časopisů z oblasti pedagogiky a didaktiky biologie. Představují možné př́stupy $\mathrm{k}$ hodnocení národních časopisů a modelově aplikují citační metriku založenou na hodnocení redakční rady z pohledu individuální vědecké výkonnosti jejích členů. Vědecká výkonnost je hodnocena na základě hodnoty H-indexu WOS. Př́i interpretaci výsledkủ berou autoři v úvahu řadu limitujících faktorů. Role redakční rady je $\mathrm{v}$ procesu vydávání časopisu nezpochybnitelná, jak v rovině vysoké odbornosti, tak v rovině lidských kvalit jejích členů. $\mathrm{V}$ procesu tzv. gatekeepingu, tedy rozhodováni o vpuštěni (etnografický výzkum pracuje s pojmem vrátný, gatekeeper, který symbolicky nebo fakticky zprostředkovává vstup do daného prostředí), však sehrávají podstatnou úlohu recenzenti, jejichž výběr redakční rada ovlivňuje. Těžiště rozhodování o kvalitě rukopisů (zejména při dvojitě slepému recenzování) leží primárně na recenzentech. Studie otevírá otázku, zda platným členem redakční rady musí být vždy pouze „držitel“ systémem vysoce hodnoceného publikačního výsledku.

Jan Hábl přibližuje koncepci projektu Komenský 2020, který formou interaktivní knihy a videí pracuje $s$ konceptem morální imaginace jako způsobu pozitivního uvažování o jevech a institucích dnešního světa. Inspirací je Komenského dílo De rerum humanarum emendatione consultatio catholica (Obecná porada o nápravě věcí lidských), které je dnes vnímáno jako ideový kšaft, testament tohoto pozoruhodného muže. Jde o dílo mimořádné nejen svým myšlenkovým nábojem, ale také osudem. První verze shořela př́i požáru Lešna na konci dubna 1656, kde vzaly za své i jiné práce, zejména nedocenitelný Poklad jazyka českého, na kterém Komenský pracoval od studentských let (!!). Na sklonku života se autor dočkal vydání prvních dvou dílů Porady, ostatních 
pět se ztratilo a byly objeveny až na počátku 20. století: „Porada je míněna tak, aby na ní měly účast všechny národy světa, které jsou rozděleny a vzájemně si odcizeny různými názory na věci. [...] Nikomu nechci vyčítat jeho vady, nikomu nechci vyčítat jeho chyby, nikoho nechci přímo ani nepřímo urážet. [...] Přestaňte vést války, začínejte zasévat mír, hlavy světa!“

Na publikaci Albína Škoviera Metody resocializačni výchovy upozorňuje svou recenzí Erich Petlák. Oceňuje prrínos knihy nejen pro speciální pedagogy, ale i pro učitele, kteří se ve škole potýkají s problémovým chováním žáků. Vedle náležitého teoretického ukotvení tématu je publikace obohacena o autorovy vysvětlující komentáře, vzniklé na základě dlouholeté zkušenosti $\mathrm{z}$ výchovné práce $\mathrm{v}$ resocializačních zařízeních. Recenzent hodnotí knihu jako „vynikající príručku výchovné práce“, ze které mohou čerpat nejen učitelé, ale i studenti učitelských oborů.

Přejeme zajímavé a podnětné čtení.

doc. PaedDr. Hana Horká, CSc.

Masarykova univerzita, Pedagogická fakulta, katedra pedagogiky;

e-mail: horka@ped.muni.cz

Mgr. Veronika Rodová, Ph.D.

Masarykova univerzita, Pedagogická fakulta, katedra primárni pedagogiky;

e-mail:rodova@ped.muni.cz 